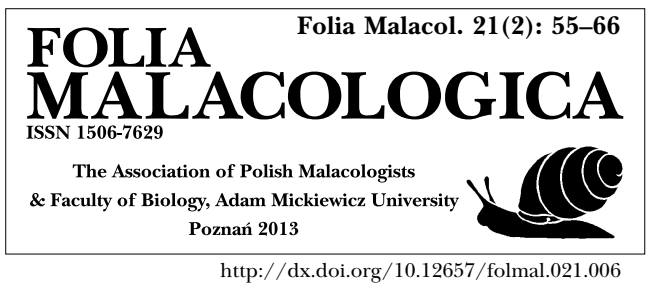

\title{
NEW BYTHINELLA SPECIES FROM NORTHERN ROMANIA (GASTROPODA: RISSOOIDEA)
}

\author{
PETER GLÖER \\ Biodiversity Research Laboratory, Schulstrasse 3, D-25491 Hetlingen, Germany (e-mail: gloeer@malaco.de) \\ ABSTRACT: Recent samples of freshwater molluscs from Romania contained six new Bythinella species: $B$. \\ blidariensis n. sp., B. georgievi n. sp., B. falniowskii n. sp., B. feheri n. sp., B. sirbui $\mathrm{n}$. sp., and B. szarowskae n. sp. \\ Since B. molcsanyi H. Wagner, 1941 sometimes co-occurred with B. grossui Falniowski, Szarowska et Sîrbu, 2009 \\ or with $B$. feheri $\mathrm{n}$. sp., differences between these species were studied, to identify diagnostic features. Apart \\ from shell morphology, also the tubular gland proved to be important for identification of Bythinella spp.
}

KEY WORDS: Bythinella, new species, Romania, tubular gland, identification

\section{INTRODUCTION}

Species of the genus Bythinella Moquin-Tandon, 1856 are distributed from Europe to Turkey and North Africa. They inhabit springs and caves in the mountains (BOETERS 1998). The highest species richness is known from France and the Balkan Peninsula (GEORGIEV \& STOYCHEVA 2011). Passive dispersal of photophobic species is difficult due to their habitat preferences, thus most of the species are locally endemic (GLÖER \& GEORGIEV 2011).

While BIELZ (1863) and KIMAKOWICZ (1883) did not report on Bythinella spp. from Romania, GROssu (1956: 99-102) listed the following Bythinella taxa: $B$. molcsanyi H. Wagner, 1941, B. dacica Grossu, 1946, B. austriaca (v. Frauenfeld, 1859), and B. austriaca var. melanostoma Brančsik, 1889. BRANČsIK (1889) described four new Bythinella spp. from Trenčsín (Slovakia), and GROSSU (1956: 102) believed that one of them (B. austriaca var. melanostoma) occurs in Romania (Valea Arieşului), more than $600 \mathrm{~km}$ away from Trenčsín. However, in his checklist published in 1986 (GROsSU
1986: 245) he deleted B. austriaca var. melanostoma. GLÖER (2002: 166) cited JAECKEL (1962: 46), who mentioned B. ehrmanni Pax, 1938 from Herkulesbad (W Romania), but this species was described from Poland (PAX 1938: 380) and should not be present in Romania. GlÖER \& SîRBU (2006) listed only $B$. austriaca and B. molcsanyi from the Inner Carpathian Basin. In summary, I agree with FALNIOWSKI et al. (2009a, b) that only B. molcsanyi $\mathrm{H}$. Wagner, 1941 and B. dacica Grossu, 1946 were known from Romania prior to recognition of four new species in the Romanian fauna: B. grossui Falniowski, Szarowska et Sîrbu 2009, B. radomanii Falniowski, Szarowska et Sîrbu 2009, B. calimanica Falniowski, Szarowska et Sîrbu 2009, and B. viseuiana Falniowski, Szarowska et Sîrbu 2009.

This paper is intended to improve the knowledge of Bythinella spp. in Romania and to describe new Bythinella spp.

\section{MATERIAL AND METHODS}

Dr. ZOLTÁN FeHÉR (Hungarian Natural History Museum, Budapest) collected 19 samples of Bythinella spp. in Romania in May 2009 (Fig. 1, Table 1). The

snails were collected by hand and with a sieve from freshwater habitats. The samples were put into $75 \%$ ethanol. The dissections and measurements of genital 


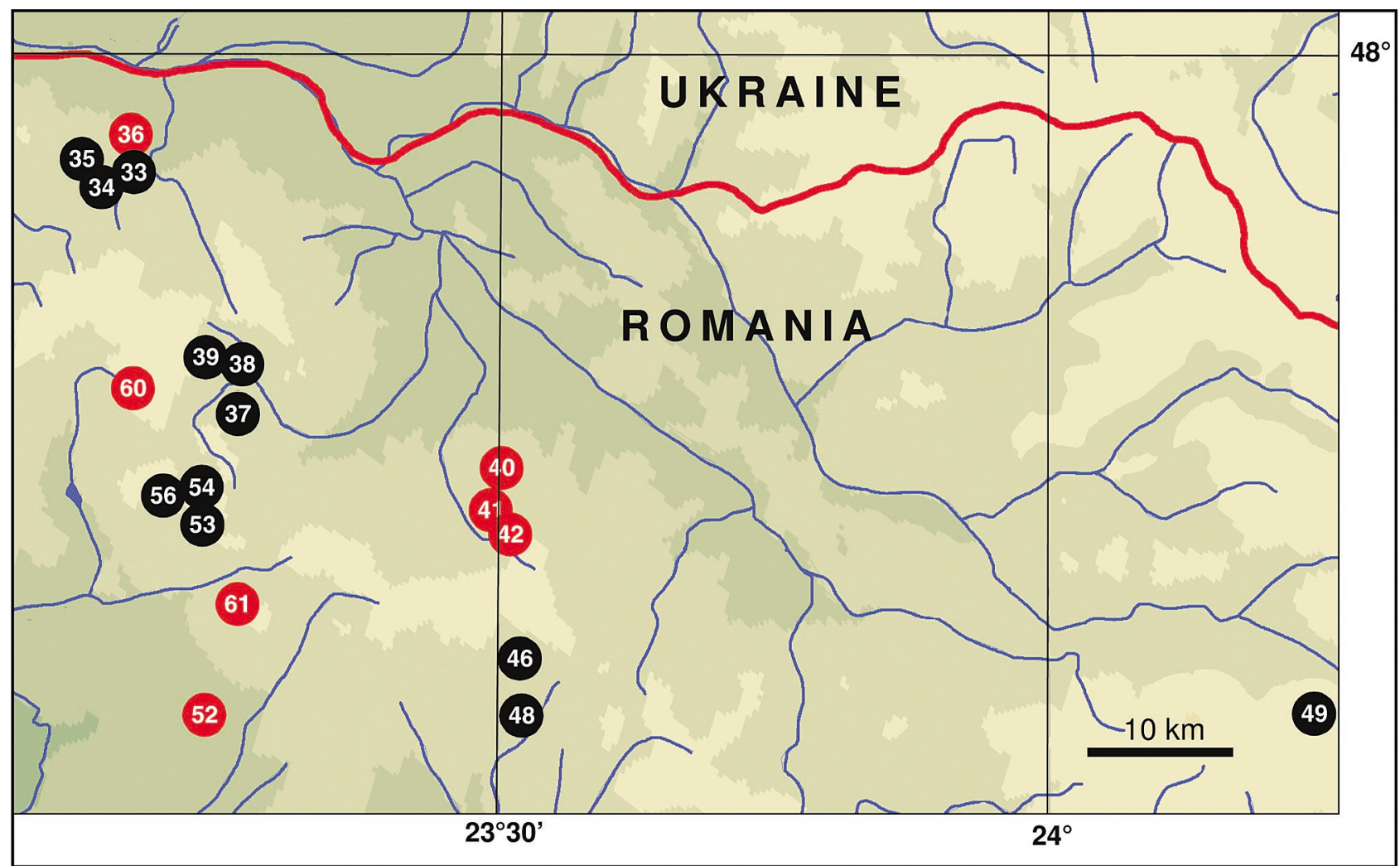

Fig. 1. Sampling sites of Bythinella spp. from Romania. The numbers refer to Table 1 (red dots - new species): $33-B$. grossui, $34-$ B. grossui, 35 - B. grossui, $36-$ B. georgievi n. sp., $37-$ B. molcsanyi, $38-$ B. grossui + B. molcsanyi, 39 - B. grossui, $40-$ B. falniowskii n. sp., 41 - B. feheri n. sp., 42 - B. falniowskii n. sp., 46 - B. grossui, 48 - B. grossui, 49 - B. viseuiana, 52 - B. sirbui n. sp., 53 - B. molcsanyi + B. grossui, $54-$ B. molcsanyi + B. feheri n. sp., $56-$ B. molcsanyi, $60-$ B. blidariensis n. sp., $61-$ B. szarowskae n. sp.

Table 1. Sampling sites of Bythinella spp. in N Romania

\begin{tabular}{|c|c|c|c|c|}
\hline Site no. & $\begin{array}{c}\text { Taxon } \\
\text { (no. of specimens) }\end{array}$ & Sampling site & $\begin{array}{l}\text { Altitude } \\
(\mathrm{m})\end{array}$ & $\begin{array}{l}\text { Geographic } \\
\text { coordinates }\end{array}$ \\
\hline $033 \mathrm{RO}$ & B. grossui $(44)$ & 6 km S of Săpânța, mineral water spring & 388 & $47^{\circ} 56^{\prime} \mathrm{N}, 23^{\circ} 41^{\prime} \mathrm{E}$ \\
\hline $034 \mathrm{RO}$ & B. grossui $(68)$ & Săpânța, $1 \mathrm{~km}$ upstream of Sipot waterfall & 651 & $47^{\circ} 55^{\prime} \mathrm{N}, 23^{\circ} 38^{\prime} \mathrm{E}$ \\
\hline $035 \mathrm{RO}$ & B. grossui $(27)$ & Săpânța, Sipot waterfall & 730 & $47^{\circ} 56^{\prime} \mathrm{N}, 23^{\circ} 37^{\prime} \mathrm{E}$ \\
\hline $036 \mathrm{RO}$ & B. georgievi n. sp. (37) & Săpânța & 398 & $47^{\circ} 55^{\prime} \mathrm{N}, 23^{\circ} 41^{\prime} \mathrm{E}$ \\
\hline $037 \mathrm{RO}$ & B. molcsanyi $(2)$ & Mara Tatargorge & 680 & $47^{\circ} 48^{\prime} \mathrm{N}, 23^{\circ} 46^{\prime} \mathrm{E}$ \\
\hline $038 \mathrm{RO}$ & $\begin{array}{l}\text { B. grossui }(21) \\
\text { B. molcsanyi }(48)\end{array}$ & Ignis plateau, Pleca & 845 & $47^{\circ} 49^{\prime} \mathrm{N}, 23^{\circ} 44^{\prime} \mathrm{E}$ \\
\hline $039 \mathrm{RO}$ & B. grossui $(31)$ & Ignis plateau, Plesca & 843 & $47^{\circ} 50^{\prime} \mathrm{N}, 23^{\circ} 45^{\prime} \mathrm{E}$ \\
\hline $040 \mathrm{RO}$ & B. falniowskii n. sp. (54) & Barsana Mori valley & 463 & $47^{\circ} 45^{\prime} \mathrm{N}, 24^{\circ} 03^{\prime} \mathrm{E}$ \\
\hline $041 \mathrm{RO}$ & B. feheri $\mathrm{n} . \mathrm{sp} .(35)$ & Barsana & 614 & $47^{\circ} 44^{\prime} \mathrm{N}, 24^{\circ} 03^{\prime} \mathrm{E}$ \\
\hline $042 \mathrm{RO}$ & B. falniowskii n. sp. (23) & Poieni de Miron & 867 & $47^{\circ} 43^{\prime} \mathrm{N}, 24^{\circ} 02^{\prime} \mathrm{E}$ \\
\hline $046 \mathrm{RO}$ & B. grossui $(52)$ & Botzia & 563 & $47^{\circ} 39^{\prime} \mathrm{N}, 24^{\circ} 08^{\prime} \mathrm{E}$ \\
\hline $048 \mathrm{RO}$ & B. grossui $(99)$ & Botzia Hudipeak & 906 & $47^{\circ} 36^{\prime} \mathrm{N}, 24^{\circ} 08^{\prime} \mathrm{E}$ \\
\hline $049 \mathrm{RO}$ & B. viseuiana $(36)$ & Statiunea Borsa & 1001 & $47^{\circ} 36^{\prime} \mathrm{N}, 24^{\circ} 47^{\prime} \mathrm{E}$ \\
\hline $052 \mathrm{RO}$ & B. sirbui n. sp. (45) & Sighetu Marmației, Baia Mare & 953 & $47^{\circ} 43^{\prime} \mathrm{N}, 23^{\circ} 45^{\prime} \mathrm{E}$ \\
\hline $053 \mathrm{RO}$ & $\begin{array}{l}\text { B. molcsanyi }(85) \\
\text { B. grossui }(4)\end{array}$ & Sighetu Marmației, Baia Mare, Izvoare & 1028 & $47^{\circ} 43^{\prime} \mathrm{N}, 23^{\circ} 45^{\prime} \mathrm{E}$ \\
\hline $054 \mathrm{RO}$ & $\begin{array}{l}\text { B. feheri n. sp. (14) } \\
\text { B. molcsanyi (11) }\end{array}$ & $7 \mathrm{~km}$ of Sighetu Marmației, Baia Mare & 947 & $47^{\circ} 44^{\prime} \mathrm{N}, 23^{\circ} 45^{\prime} \mathrm{E}$ \\
\hline $056 \mathrm{RO}$ & B. molcsanyi $(21)$ & Sighetu Marmatiei, Baia Mare, Izvoare & 916 & $47^{\circ} 45^{\prime} \mathrm{N}, 23^{\circ} 43^{\prime} \mathrm{E}$ \\
\hline $060 \mathrm{RO}$ & B. blidariensis n. sp. (54) & Blidari V. Neagra junction & 528 & $47^{\circ} 48^{\prime} \mathrm{N}, 23^{\circ} 37^{\prime} \mathrm{E}$ \\
\hline $061 \mathrm{RO}$ & B. szarowskae n. sp. (71) & Mogosa & 714 & $47^{\circ} 40^{\prime} \mathrm{N}, 23^{\circ} 46^{\prime} \mathrm{E}$ \\
\hline
\end{tabular}


organs and shells were carried out using a stereo microscope (Zeiss); photographs of the shells and the genital anatomy were taken with a digital camera system (Leica R8).

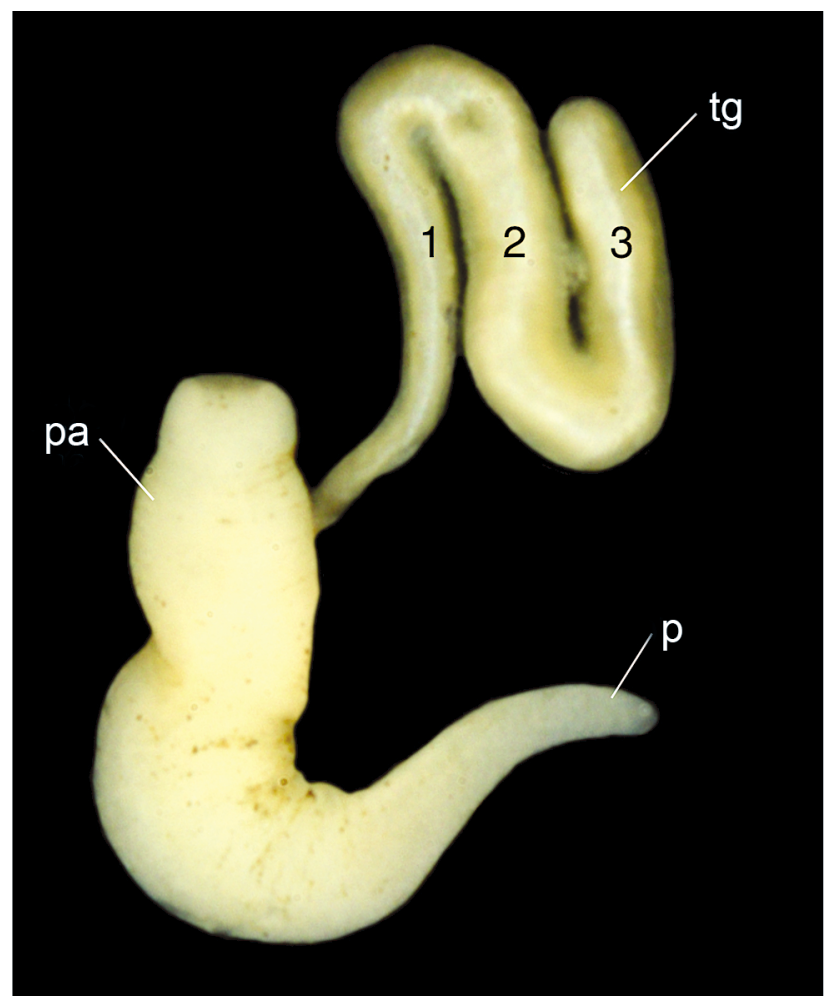

Fig. 2. Male genital organ of Bythinella: p - penis, pa penial appendix, $\operatorname{tg}-$ tubular gland with 3 half loops
To identify Bythinella spp., the following features have been applied: (i) shell morphology: height, ratio of shell height to the width of the last whorl $(\mathrm{H}: \mathrm{W})$, aperture height to shell height ratio $(\mathrm{A}: \mathrm{H})$, umbilicus type, aperture shape, and (ii) the male copulatory organ (Fig. 2): length ratio of the penis to the penial appendix, number of half loops of the tubular gland, and width of the proximal and distal parts of the tubular gland. The tubular gland is not considered by many authors, but it is an important feature to distinguish Bythinella spp. To select constant features of the male copulatory organ, it was studied in at least three specimens from every sample. Shell variability was assessed on the basis of measurements.

The female reproductive system is not considered here because the differences did not provide any useful features to distinguish between the Bythinella spp. under discussion.

For species delimitation, I had to work with the morphological species concept (QUEIROZ 2005, SINGH 2012), based on features that are intraspecifically constant but interspecifically different. A good test was that there were three samples in which the Bythinella specimens could be separated into two distinct clusters each, identified as B. molcsany $i$ and $B$. grossui (038RO, 053RO: Fig. 3, Table 1), or B. molcsany $i$ and $B$. feheri n. sp. (054RO: Table 1), respectively. Sympatric populations confirm indirectly the biological species concept, which could support the morphological species concept in this case. In addition, morphological distinctness of B. molcsanyi and B. grossui

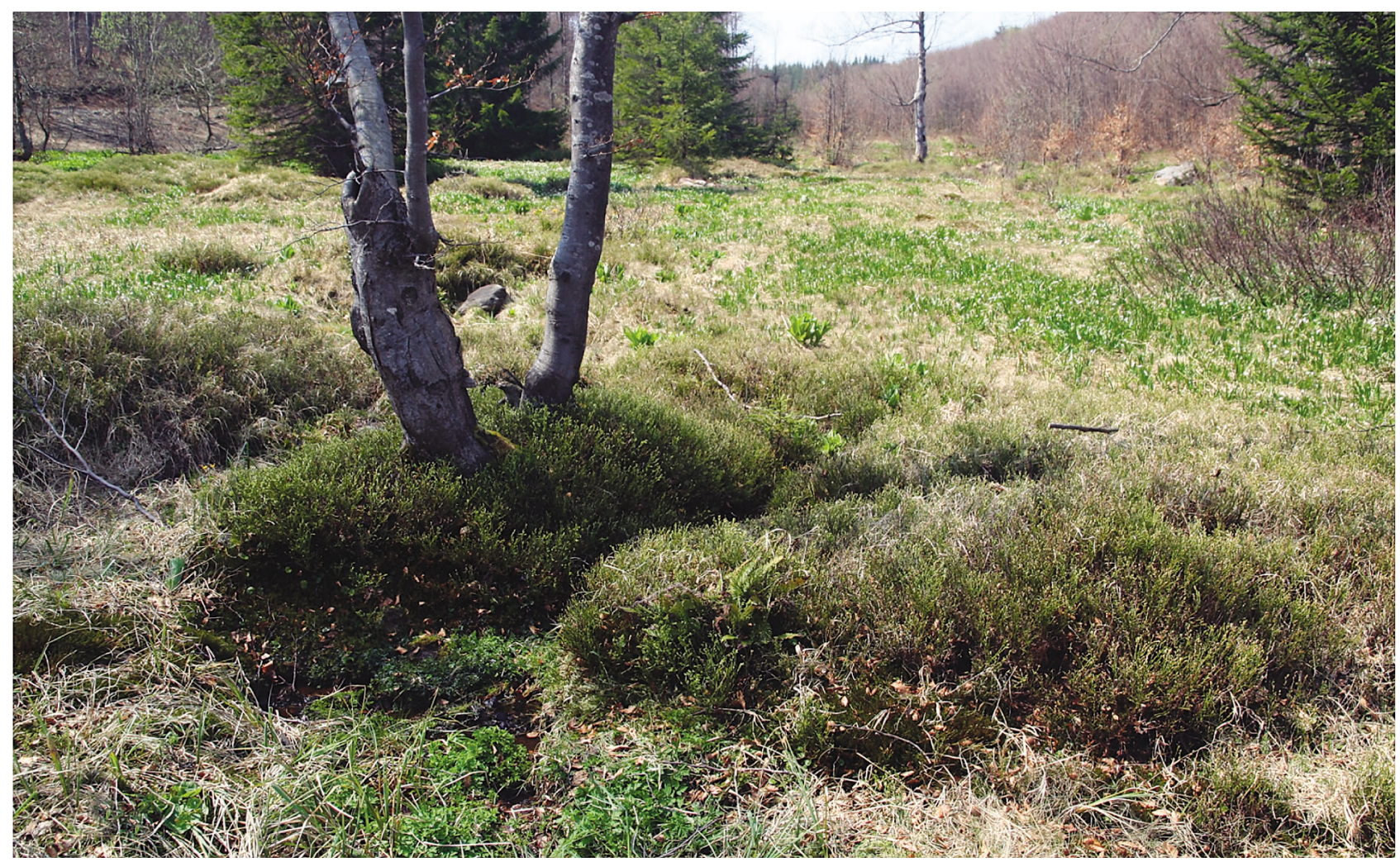

Fig. 3. Sampling site of syntopic populations of Bythinella molcsanyi and B. grossui 


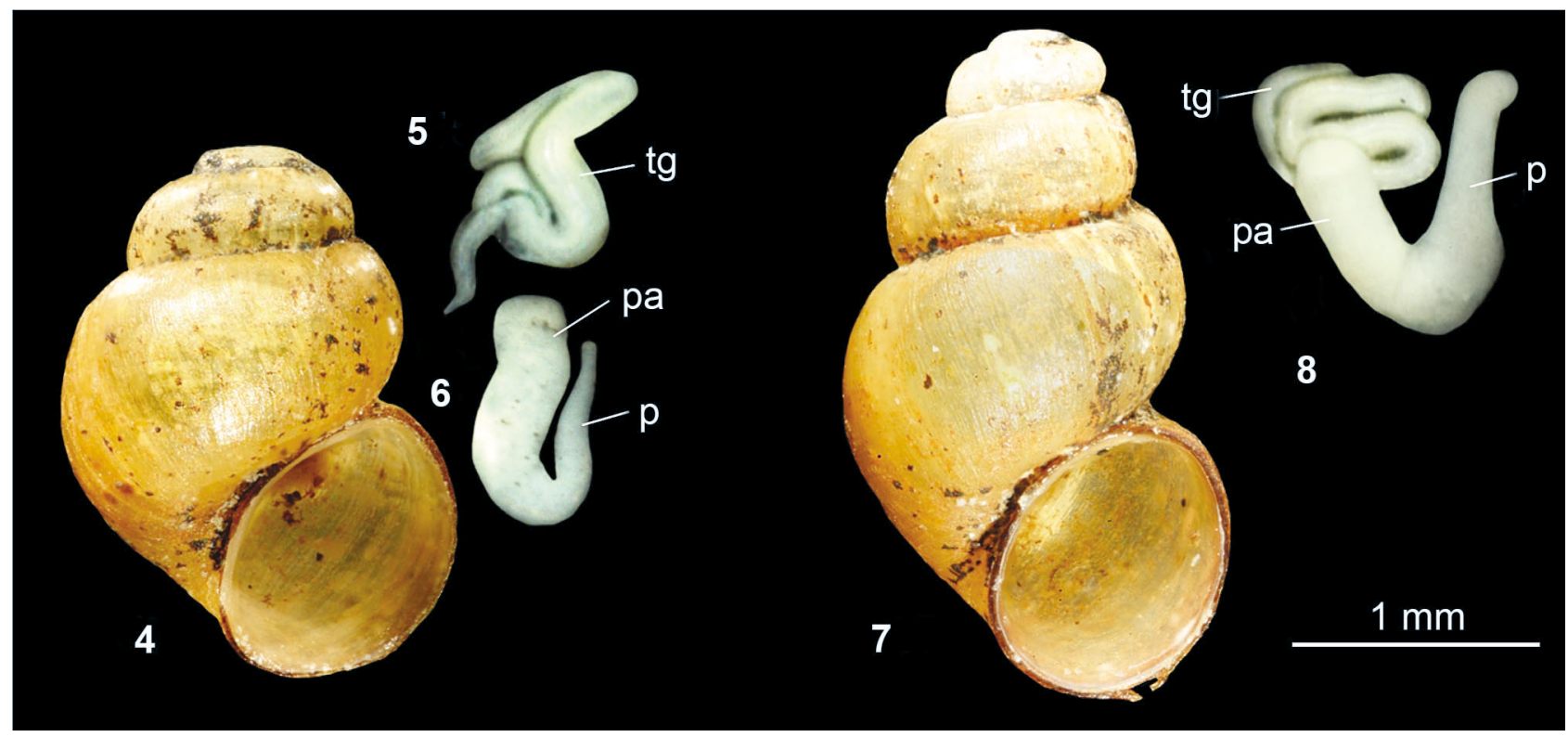

Figs 4-8. Syntopic specimens of Bythinella molcsanyi (4-6) and B. grossui (7-8); p - penis, pa - penial appendix, tg - tubular gland

(Figs 4-8) has already been confirmed by sequencing of the mitochondrial cytochrome oxidase subunit I (COI) gene (FALNIOWSKI et al. 2009a).

\section{RESULTS}

Identification of Bythinella spp. is not easy because these species have only few distinguishing features. Therefore, only the differentiating features have been used for species description. The following diagnostic features were recognized in this study: (i) shell size, (ii) morphometry of the tubular gland, and (iii) proportions of the penis and penial appendix. The main feature is the tubular gland, which can be (i) evenly thick
All materials are stored in the Hungarian Natural History Museum (HNHM) and some paratypes in my own collection.

Table 2. Distinguishing features of Bythinella spp. in N Romania

\begin{tabular}{|c|c|c|c|c|c|c|c|c|c|}
\hline Species & $\mathrm{H}$ & $\mathrm{H}: \mathrm{W}$ & A:H & $\begin{array}{l}\text { Umbili- } \\
\text { cus }\end{array}$ & $\begin{array}{l}\text { Aperture } \\
\text { shape }\end{array}$ & $\begin{array}{c}\text { Penis/ } \\
\text { penial } \\
\text { appendix }\end{array}$ & $\begin{array}{l}\text { Tubular } \\
\text { gland } \\
\text { prox. }\end{array}$ & $\begin{array}{c}\text { Tubular } \\
\text { gland } \\
\text { dist. }\end{array}$ & $\begin{array}{c}\text { Tubular } \\
\text { gland } \\
\text { half } \\
\text { loops }\end{array}$ \\
\hline B. blidariensis $\mathrm{n} . \mathrm{sp}$. & 1 & 1.8 & 0.37 & 0 & 0 & 2 & 0 & 2 & 5 \\
\hline B. falniowskii n. sp. & 2 & 1.8 & 0.40 & 0 & 2 & 3 & 0 & 1 & 3 \\
\hline B. feheri n. sp. & 1 & 1.8 & 0.43 & 0 & 2 & 2 & 0 & 1 & 3 \\
\hline B. georgievi $\mathrm{n} . \mathrm{sp}$. & 1 & 1.6 & 0.43 & 0 & 0 & 3 & 0 & 2 & 4 \\
\hline B. grossui & 1 & 1.8 & 0.43 & 0 & 0 & 4 & 0 & 2 & 6 \\
\hline B. molcsanyi & 0 & 1.4 & 0.45 & 0 & 1 & 2 & 1 & 2 & 5 \\
\hline B. sirbui n. sp. & 2 & 1.6 & 0.41 & 1 & 0 & 1 & 2 & 2 & 5 \\
\hline B. szarowskae $\mathrm{n}$. sp. & 1 & 1.7 & 0.36 & 1 & 0 & 2 & 1 & 3 & 3 \\
\hline B. viseuiana & 1 & 1.7 & 0.45 & 0 & 2 & 2 & 0 & 2 & 7 \\
\hline
\end{tabular}

$\mathrm{H}$ - mean shell height: $<2.5-0 ; 2.5-3.0-1 ;>3-2 ; \mathrm{H}: \mathrm{W}-$ shell height to width ratio; A:W - aperture height to shell height ratio; umbilicus: closed -0 , slit-like -1 ; aperture shape: oval -0 , circular -1 , oval angled -2 ; penis to penial appendix ratio: 0.25:1 - 1, 1:1 - 2, 0.75:1 3, 1.25:1 - 4; tubular gland proximally: slightly thinner than middle part -0 , much thinner -1 , thread-like -2 ; tubular gland distally: thickened -1 , of similar thickness as middle part -2 , club-shaped -3 ; tubular gland half loops: number is given. 


\section{IDENTIFICATION KEY OF BYTHINELLA SPP. OF NORTHERN ROMANIA}

For identification, mainly the features presented in Table 2 are used. For nomenclature of the male copulatory organ, see Fig. 2. Abbreviations: tgl - tubular gland half loops, $\mathrm{H}: \mathrm{W}$ - shell height to width ratio, A:H - aperture height to shell height ratio.

1. $\quad 6-7$ tgl, shell medium-sized (height $2.5-2.9 \mathrm{~mm}$ ), umbilicus closed

1'. $<6$ tgl

2. 6 tgl, penial appendix shorter than penis, tg nearly evenly thick

B. grossui (Figs 7-8)

2'. 7 tgl, penial appendix as long as penis, tg nearly evenly thick, slightly thinner proximally

3. $\quad$ shell small but broad (height 1.9-2.4 mm, width 1.4-1.7 mm, H:W= 1.4), umbilicus closed, tg much thinner proximally, $5 \mathrm{tgl}$

B. molcsanyi (Figs 4-6)

3'. $\quad$ shell higher than $2.4 \mathrm{~mm}$

4. $\quad 5$ tgl, shell medium-sized (2.6-3.1 mm)

4 '. $\quad<5$ tgl, tg thinner proximally

5. shell broad (height $2.9-3.1 \mathrm{~mm}$, width $1.7-2.0 \mathrm{~mm}$ ), $\mathrm{H}: \mathrm{W}=1.6, \mathrm{~A}: \mathrm{H}=$ 0.41 , umbilicus slit-like, tg thread-like proximally

5'. $\quad$ shell slim (height 2.8-3.3 mm, width 1.5-1.7 mm), H:W=1.8, A:H = 0.37 , umbilicus closed, tg nearly evenly thick

B. blidariensis (p. 65, Figs 26-27)

6. 4 tgl, shell large and broad (height $2.8-3.5 \mathrm{~mm}$, width $1.8-2.0 \mathrm{~mm}$ ), $\mathrm{H}: \mathrm{W}=1.6, \mathrm{~A}: \mathrm{H}=0.43$, tg as long as penis

B. georgievi (p. 62, Figs 17-18)

6'. $\quad 3$ tgl, shell height $2.7-3.5 \mathrm{~mm}$

7. $\quad$ shell large (height 3.2-3.5 mm), umbilicus closed, penial appendix longer than penis, tg slightly thinner proximally

B. falniowskii (p. 59, Figs 11-13)

7'. $\quad$ shell medium-sized $(2.7-3.1 \mathrm{~mm})$

8. shell slim (width $1.5-1.7 \mathrm{~mm}$ ), A:H = 0.36, umbilicus slit-like, tg club-shaped distally

B. szarowskae (p. 62, Figs 14-16)

8'. $\quad$ shell broader (1.5-2.0 mm), A:H $=0.43$, umbilicus closed, tg not club-shaped distally

B. feheri (p. 62, Figs 19-22)

\section{SPECIES DESCRIPTIONS}

Genus Bythinella Moquin-Tandon, 1856

Diagnosis: Shell cylindrical with a blunt apex. Penis bearing a penial appendix with a tubular gland (Fig. 2).

\section{Bythinella falniowskii n. sp.}

Holotype: height $3.3 \mathrm{~mm}$, width $1.6 \mathrm{~mm}$, HNHM 97588

Paratypes: 54 specimens from type locality, HNHM 97589, 6 specimens coll. GLÖER; 23 specimens from 042RO Poieni de Miron, 867 m. a.s.l., $47^{\circ} 43^{\prime} \mathrm{N}$, $24^{\circ} 02^{\prime} \mathrm{E}, \mathrm{HNHM} 97578$

Locus typicus: 040RO Barsana Mori valley, $463 \mathrm{~m}$ a.s.l., $47^{\circ} 45^{\prime} \mathrm{N}, 24^{\circ} 03^{\prime} \mathrm{E}$ (Figs 9,10 )

Etymology: Named after ANDRZEJ FALNIOWSKI, an outstanding Polish expert on freshwater molluscs, who did so much for the research on Rissooidea.
Description: Shell horn-coloured, cylindrical (Figs 11, 12 ), its 4.5 whorls regularly convex, with a deep suture. Surface silky and finely striated. Apex obtuse, umbilicus closed. Aperture oval, its top angled. Shell height 3.2-3.5 mm, mean $3.35 \mathrm{~mm}(\sigma= \pm 0.14, \mathrm{n}=6)$, width $1.8-2.1 \mathrm{~mm}$, mean $1.9 \mathrm{~mm}(\sigma= \pm 0.1)$, aperture height to shell height ratio $40(\sigma= \pm 0.09)$. Penis shorter than penial appendix, tubular gland with 3 half loops, broad in middle part and attenuated proximally (Fig. 13).

Differentiating features: This species differs from the other Romanian species in its shell height and the short tubular gland with 3 half loops, which is similar to those of $B$. feheri and B. szarowskae but in the latter species the distal end of the tubular gland is bulbed. 

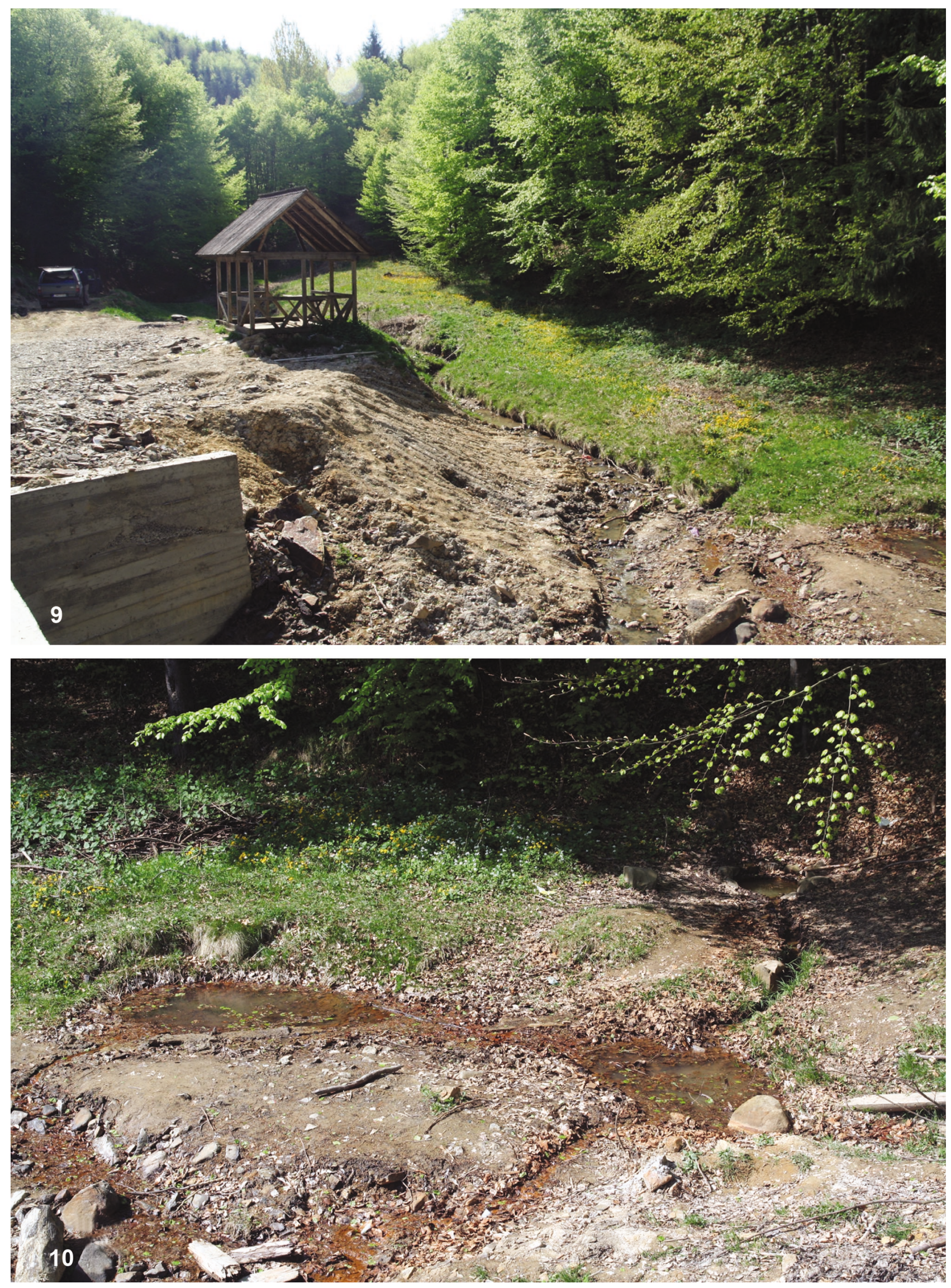

Figs 9-10. Type locality of Bythinella falniowskii n. sp. (Photo: ZOLTÁN FEHÉR) 


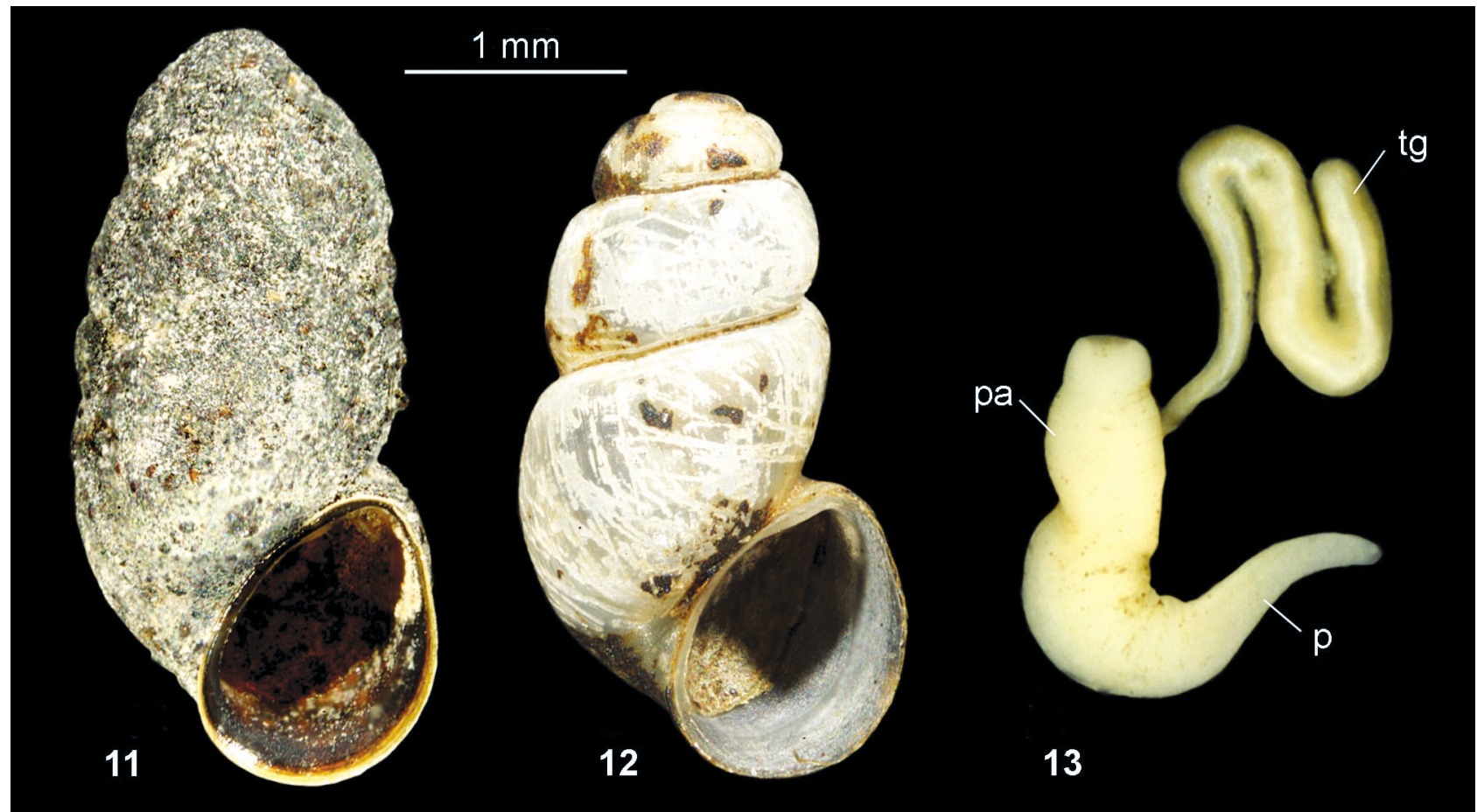

Figs 11-13. Bythinella falniowskii n. sp.: 11-12 - shell (2 - holotype), 13 - penis with tubular gland; p - penis, pa - penial appendix, tg - tubular gland

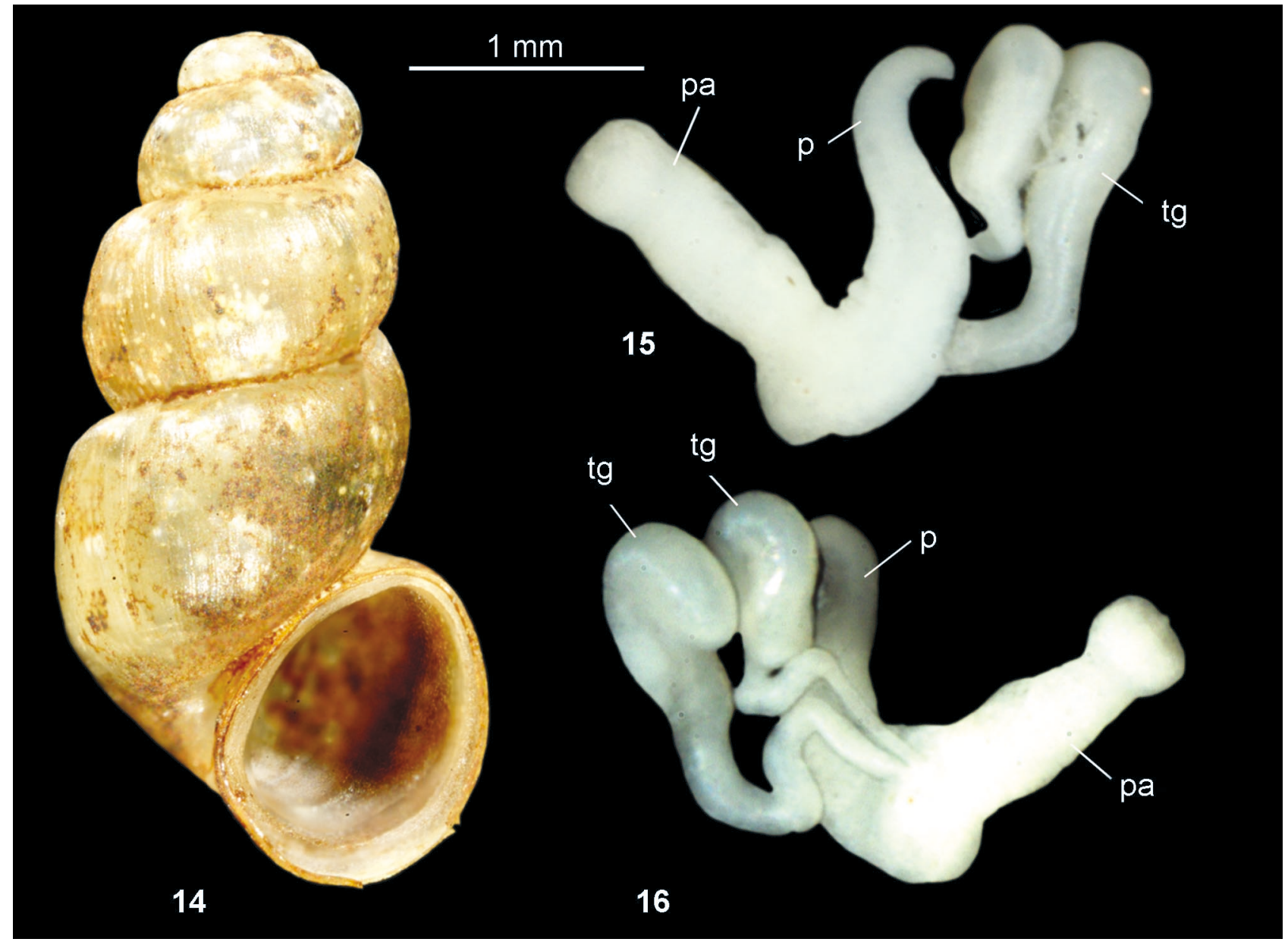

Figs 14-16. Bythinella szarowskae n. sp.: 14 - shell, 15 - penis with tubular gland, 16 - penis with 2 tubular glands; $p$ - penis, pa - penial appendix, tg - tubular gland 


\section{Bythinella szarowskae n. sp.}

Holotype: height $3.6 \mathrm{~mm}$, width $1.9 \mathrm{~mm}$, HNHM 97592

Paratypes: 71 specimens, HNHM 97593, 10 specimens coll. GLÖER, from locus typicus

Locus typicus: $061 \mathrm{RO}$ Mogosa, $714 \mathrm{~m}$ a.s.l., $47^{\circ} 40^{\prime} \mathrm{N}$, $23^{\circ} 46^{\prime} \mathrm{E}$

Etymology: Named after MAGDALENA SZAROWSKA, an outstanding Polish expert on Rissooidea, who did so much for the research on the Balkans.

Description: Shell horn-coloured, cylindrical and slim (Fig. 14), its 4.5 whorls regularly rounded, with a deep suture. Surface silky and finely striated. Apex broad and obtuse, umbilicus slit-like. Aperture oval. Shell height $2.7-3.1 \mathrm{~mm}$, mean $3.0 \mathrm{~mm}(\sigma= \pm 0.17, \mathrm{n}=11)$, width $1.5-1.7 \mathrm{~mm}$, mean $1.6 \mathrm{~mm}(\sigma= \pm 0.17)$, aperture height to shell height ratio $0.36(\sigma= \pm 0.11)$. Penis as long as penial appendix (Fig. 15), tubular gland short, with 3 half loops, thin proximally and bulbed distally. In one specimen, the penial appendix had 2 tubular glands (Fig. 16).

Differentiating features: The ratio of aperture height to shell height is 0.36 and the tubular gland is short and club-shaped at the distal end. The aperture is oval and not angled, as it is in B. falniowskii and B. feheri.

\section{Bythinella georgievi n. sp.}

Holotype: height $3.5 \mathrm{~mm}$, width $2.0 \mathrm{~mm}$, HNHM 97581
Paratypes: 37 specimens, HNHM 97582, 6 specimens coll. GLÖER, from locus typicus

Locus typicus: $036 \mathrm{RO}$ Sapanta, $398 \mathrm{~m}$ a.s.l., $47^{\circ} 56^{\prime} \mathrm{N}$, $23^{\circ} 41^{\prime} \mathrm{E}$

Etymology: Named after DILIAN GEORGIEV, an outstanding expert on freshwater molluscs of Bulgaria, who found many new Rissooidea in his country.

Description: Shell horn-coloured, cylindrical (Fig. 17 ), its 4.5 whorls regularly convex, with a deep suture. Apex obtuse, umbilicus closed. Aperture oval, with a sharp peristome. Shell height $2.8-3.5 \mathrm{~mm}$, mean $3.0 \mathrm{~mm}(\sigma= \pm 0.14, \mathrm{n}=6)$, width $1.8-2.0 \mathrm{~mm}$, mean $1.9 \mathrm{~mm}(\sigma= \pm 0.1)$, aperture height to shell height ratio $0.43(\sigma= \pm 0.12)$. Penis as long as penial appendix. Tubular gland long, with 4 half loops, not very broad but attenuated proximally (Fig. 18).

Differentiating features: The aperture of this species is oval and not angled. It has a long tubular gland with 4 half loops, slightly thinner proximally.

\section{Bythinella feheri n. sp.}

Holotype: height $2.2 \mathrm{~mm}$, width $1.5 \mathrm{~mm}$, HNHM 97583

Paratypes: 35 specimens, HNHM 97584, 6 specimens coll. GLÖER

Locus typicus: 041RO Barsana, $614 \mathrm{~m}$ a.s.1., $47^{\circ} 44^{\prime} \mathrm{N}$, $24^{\circ} 03^{\prime} \mathrm{E}$

Etymology: Named after ZOLTÁN FEHÉR, an eminent Hungarian malacologist who collected the materials.

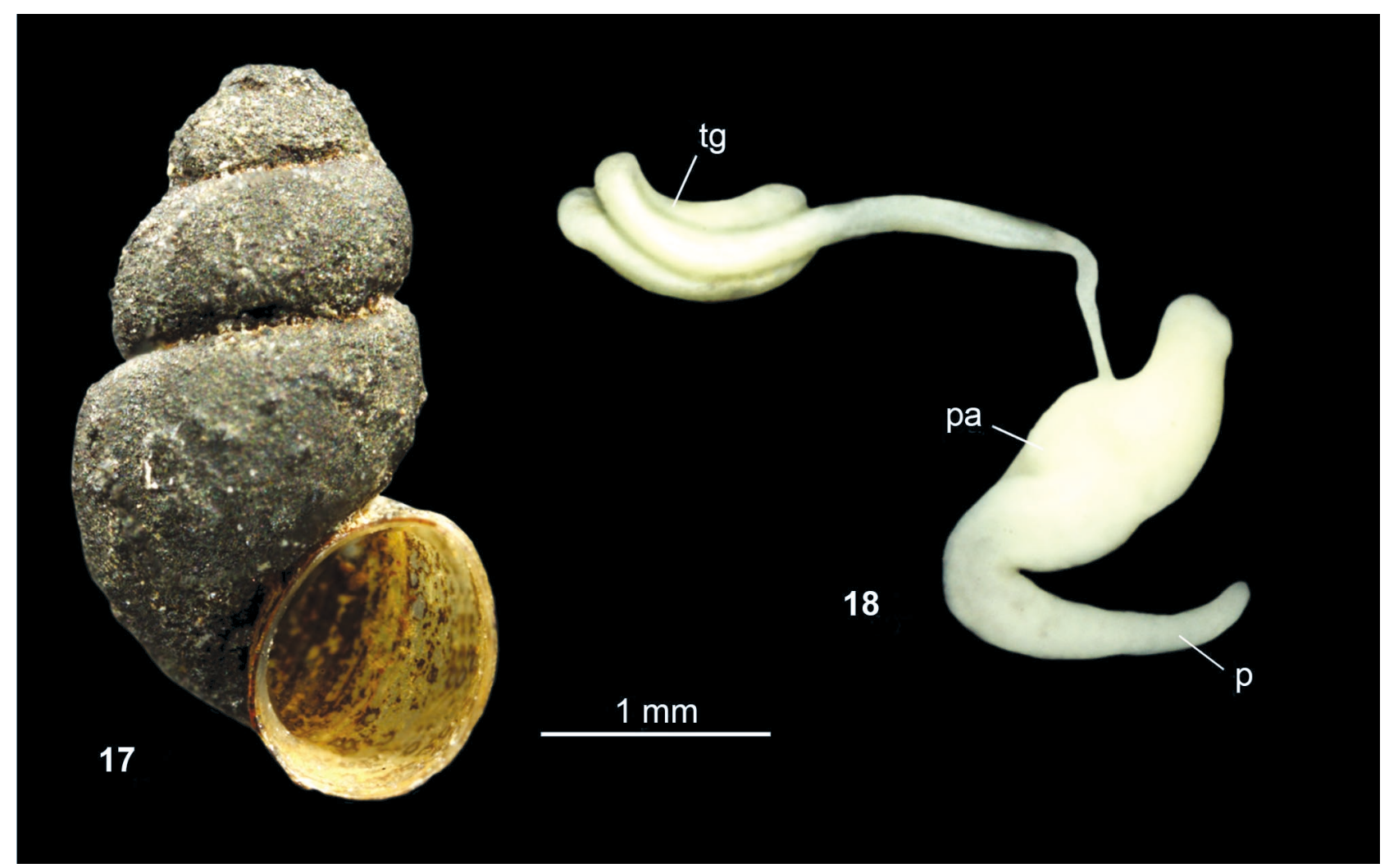

Figs 17-18. Bythinella georgievi n. sp.: 17 - shell (holotype), 18 - penis with tubular gland; p - penis, pa - penial appendix, tg - tubular gland 
Description: Shell horn-coloured, cylindrical (Figs 19, $20)$, its 4.5 whorls slightly rounded. Surface silky and finely striated. Apex small and obtuse, umbilicus closed. Aperture oval, with a sharp peristome and angled top. Shell height 2.7-3.0 mm, mean $2.9 \mathrm{~mm}(\sigma=$ $\pm 0.1, \mathrm{n}=6)$, width $1.5-2.0 \mathrm{~mm}$, mean $1.6 \mathrm{~mm}(\sigma=$ \pm 0.14 ), aperture height to shell height ratio $0.43(\sigma=$ \pm 0.14 ). Penis (Fig. 21) as long as penial appendix, tubular gland short (Fig. 22), with 3 half loops, broad distally and thin proximally.

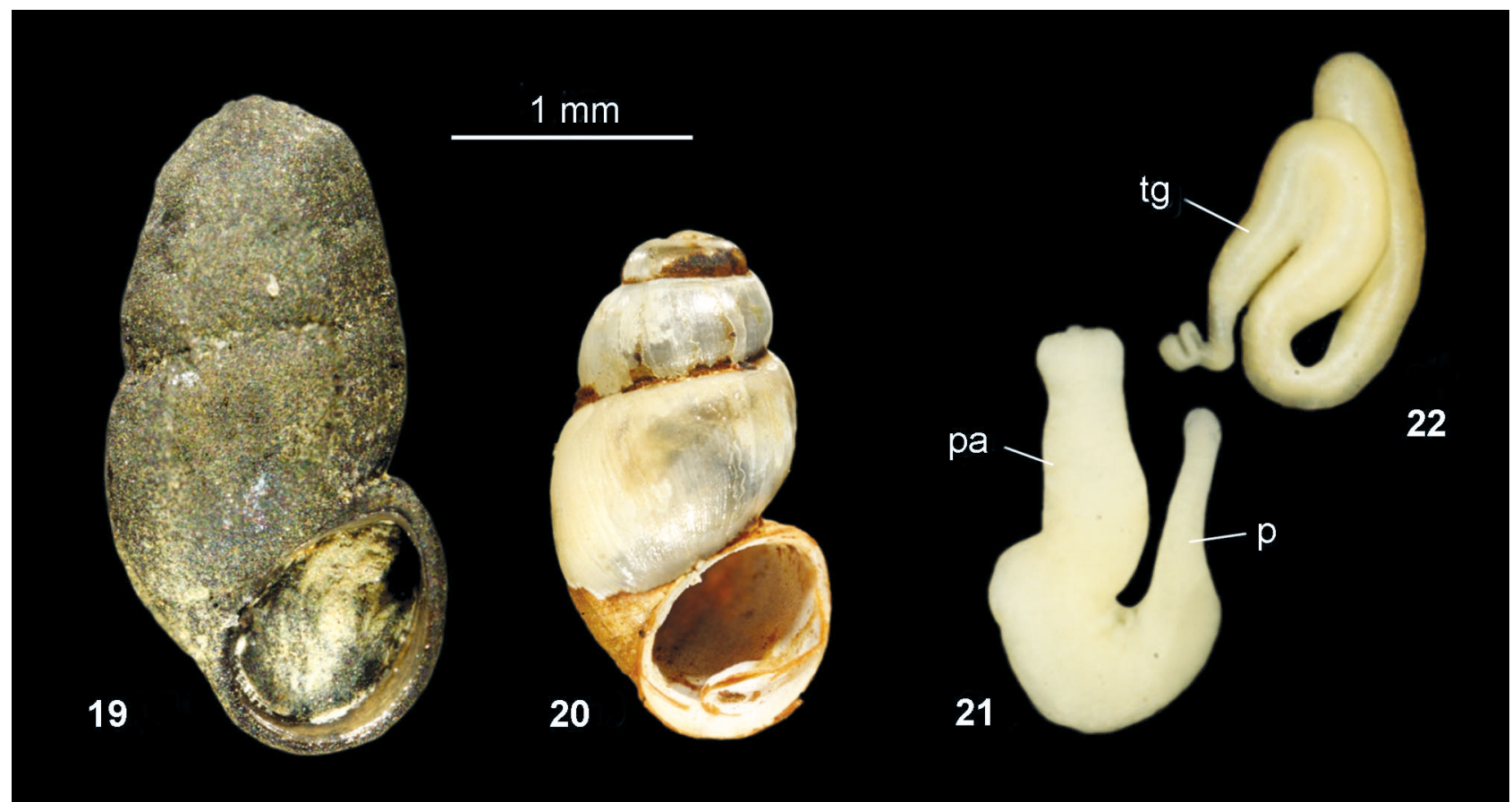

Figs 19-22. Bythinella feheri n. sp.: 19-20 - shell (20 - holotype), 21 - penis, 22 - tubular gland; p - penis, pa - penial appendix, tg - tubular gland

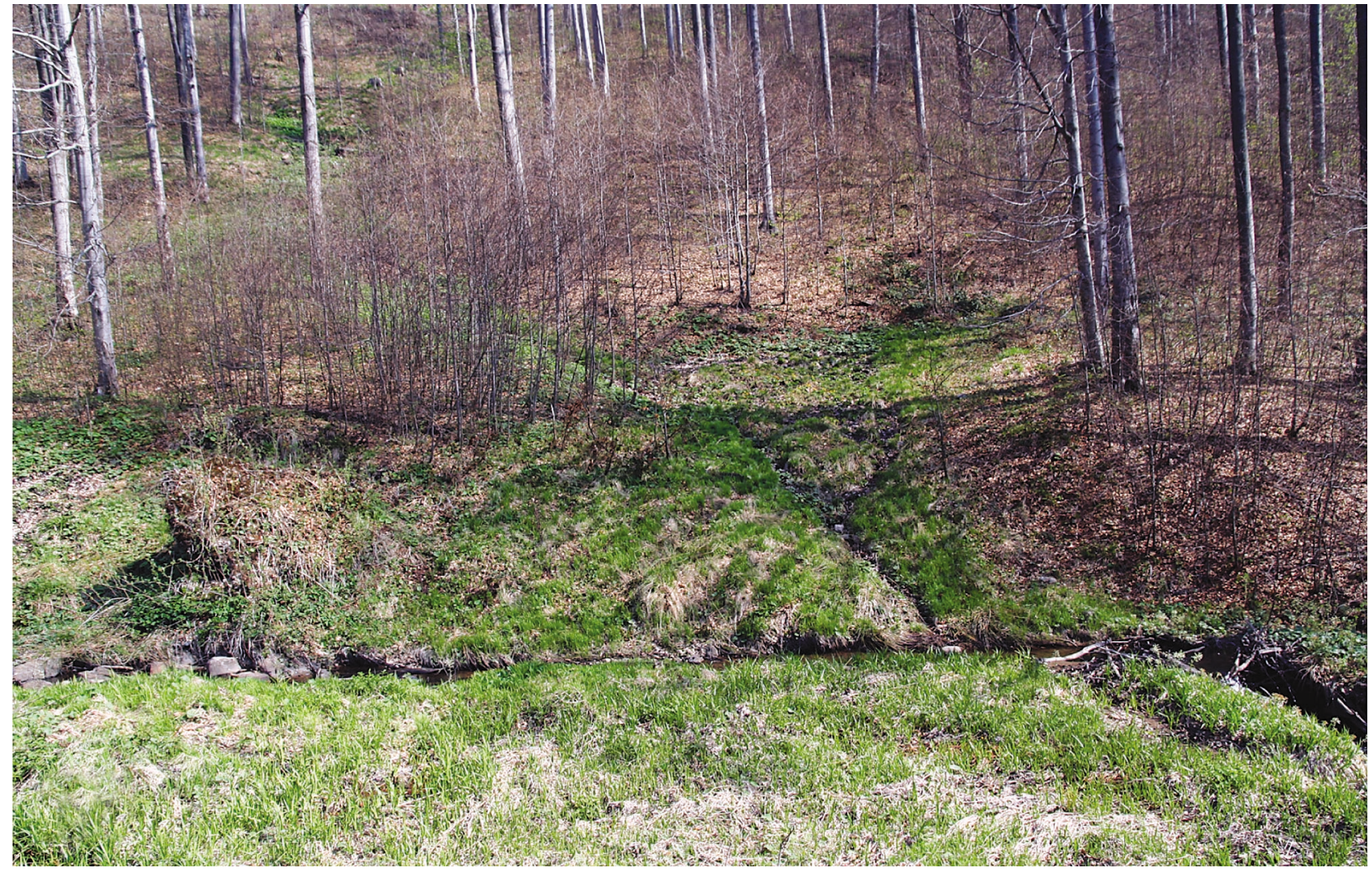

Fig. 23. Type locality of Bythinella sirbui $\mathrm{n}$. sp. 


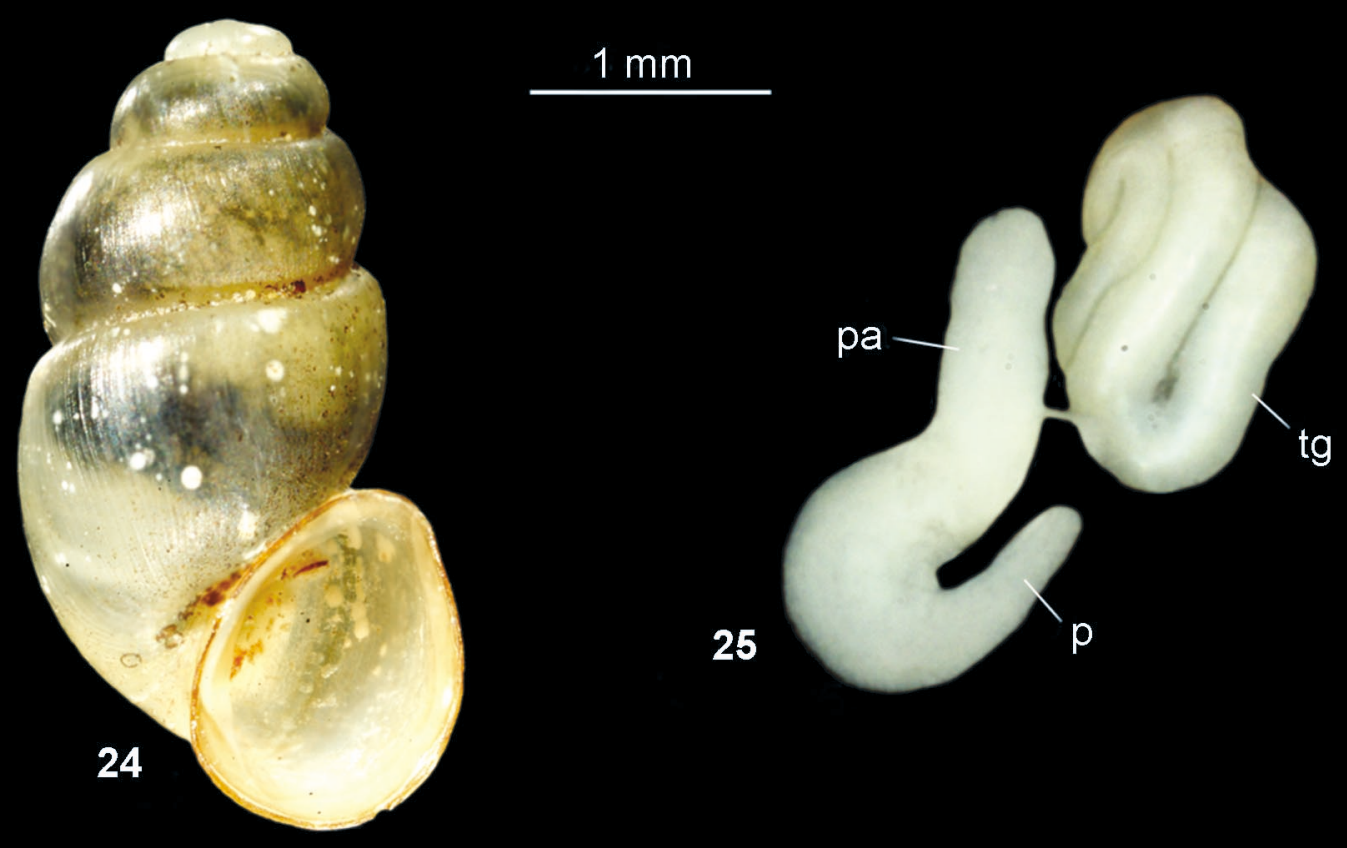

Figs 24-25. Bythinella sirbui n. sp.: 24 - shell (holotype), 25 - penis with tubular gland; p - penis, pa - penial appendix, tg tubular gland

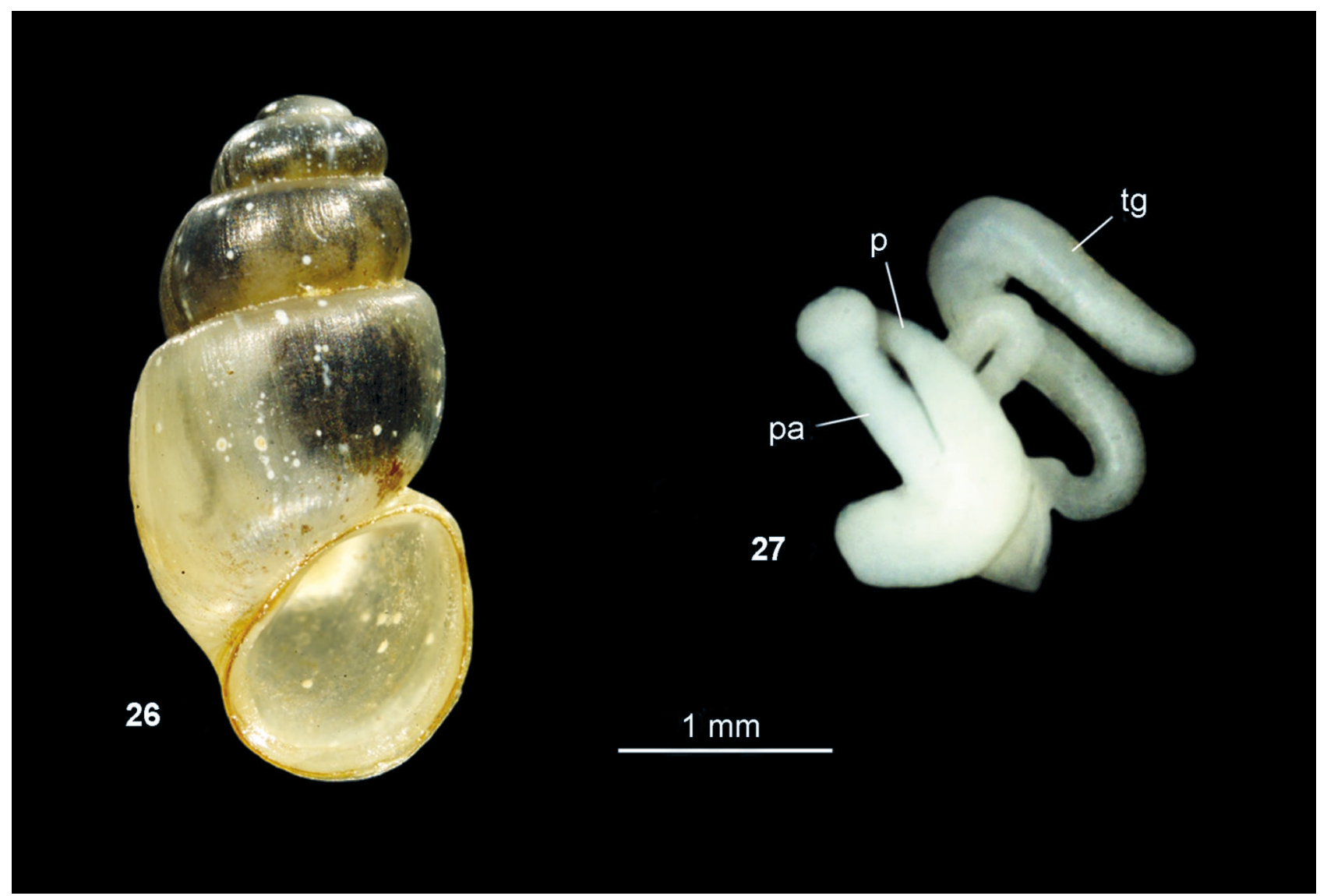

Figs 26-27. Bythinella blidariensis n. sp.: 26 - shell, 27 - penis with tubular gland; $\mathrm{p}$ - penis, pa - penial appendix, tg - tubular gland 
Differentiating features: This species differs from almost all other Bythinella spp. from Romania in its angled aperture and its short tubular gland with 3 half loops. It is smaller than the similar B. falniowskii n. sp., which has also a tubular gland with 3 half loops.

Remark: At locality 054RO it occurs together with $B$. molcsanyi. They differ in shell shape (broader in $B$. molcsanyi) and the tubular gland (shorter in B. feheri n. sp.).

\section{Bythinella sirbui n. sp.}

Holotype: height $3.5 \mathrm{~mm}$, width $1.9 \mathrm{~mm}$, HNHM 97571

Paratypes: 45 specimens HNHM 97572, 5 specimens coll. GLÖER, from locus typicus

Locus typicus: 052RO Sighetu Marmatiei-Baia Mare, $953 \mathrm{~m}$ a.s.1., $47^{\circ} 43^{\prime} \mathrm{N}, 23^{\circ} 45^{\prime} \mathrm{E}$ (Fig. 23)

Etymology: Named after IOAN SÎRBU, an outstanding expert on freshwater molluscs in Romania.

Description: Shell horn-coloured, cylindrical and slim (Fig. 24), its 4.5 whorls with a deep suture. Surface silky and finely striated. Apex broad and obtuse, umbilicus slit-like. Aperture oval, with a sharp peristome. Shell height 2.9-3.5 mm, mean $3.1 \mathrm{~mm}(\sigma= \pm 0.14$, n $=5)$, width $1.7-2.0 \mathrm{~mm}$, mean $1.8 \mathrm{~mm}(\sigma= \pm 0.1)$, aperture height to shell height ratio $0.41(\sigma= \pm 0.07)$. Penis shorter than penial appendix, tubular gland long

\section{DISCUSSION}

The syntopic species Bythinella molcsanyi and $B$. grossui, as well as $B$. feheri $\mathrm{n}$. sp. and B. molcsanyi, differ in shell proportions as well as in thickness of the proximal part of the tubular gland or length of the tubular gland. These are the main features used for species delimitation in Bythinella spp., which has already been pointed out by GLÖER \& GEORGIEV (2011). Because all specimens were collected in the same month (1-3 May 2009), the differences in the tubular gland cannot be a result of different sexual activities. A multivariate cluster analysis (Fig. 28) revealed that it is possible to distinguish the $\mathrm{N}$ Romanian Bythinella spp. from each other by the features listed in Table 2.

All Bythinella spp. from N Romania seem to be locally endemic (Fig. 1), as is the case in other mountainous countries where Bythinella spp. occur. Recent investigations of Bythinella spp. in the neighbouring Bulgaria revealed 18 distinct species (GEORGIEV 2009, GLÖER \& GEORGIEV 2011, GEORGIEV \& STOYCHEVA 2011), so it is possible that more Bythinella spp. might be found in Romania in the future. and broad, with 5 half loops, very thin proximally (Fig. 25).

Differentiating features: This species differs from the other species in its short penis. The other species with 5 half loops are smaller (B. molcsanyi) or are not thinner proximally (B. blidariensis). Tubular gland thicker than in B. georgievi.

\section{Bythinella blidariensis n. sp.}

Holotype: height $3.3 \mathrm{~mm}$, width $1.5 \mathrm{~mm}$, HNHM 97579

Paratypes: 54 specimens HNHM 97580, 8 specimens coll. GLÖER, from locus typicus

Locus typicus: 060RO Blidari V. Neagra junction, 528 $\mathrm{m}$ a.s.l., $47^{\circ} 48^{\prime} \mathrm{N}, 23^{\circ} 37^{\prime} \mathrm{E}$

Etymology: Named after the region where the species lives.

Description: Shell horn-coloured, cylindrical and slim (Fig. 26), its 4.5 whorls with a deep suture. Surface silky and finely striated. Apex obtuse, umbilicus closed. Aperture oval, with a sharp peristome. Shell height $2.8-3.3 \mathrm{~mm}$, mean $2.9 \mathrm{~mm}(\sigma= \pm 0.1, \mathrm{n}=8)$, width $1.5-1.7 \mathrm{~mm}$, mean $1.6 \mathrm{~mm}(\sigma= \pm 0.1)$, aperture height to shell height ratio $0.37(\sigma= \pm 0.09)$. Penis as long as penial appendix, tubular gland medium-sized, evenly thick (Fig. 27).

Differentiating features: The tubular gland is long and evenly thick, with 5 half loops.

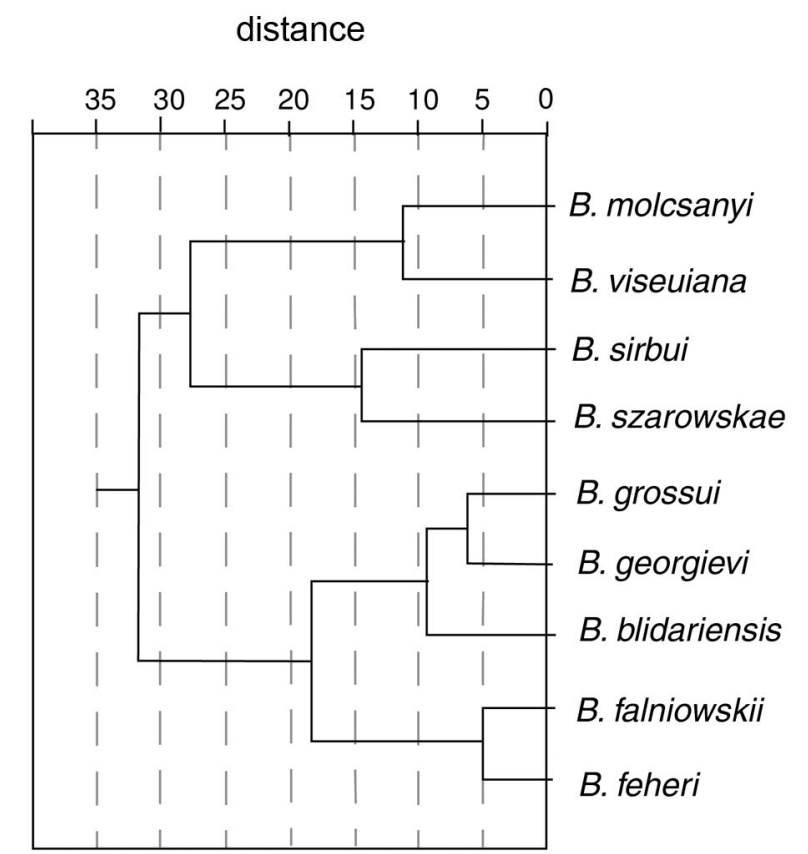

Fig. 28. Results of multivariate cluster analysis of Bythinella spp. from N Romania, using the values in Table 2 (Software: Winstat) 


\section{ACKNOWLEDGEMENTS}

I would like to thank ZOLTÁN FEHÉR who lent me the materials for the new descriptions, and DAVID

\section{REFERENCES}

BIELZ E. A. 1863. Fauna der Land- und Süsswasser-Mollusken Siebenbürgens. Th. Steinhaussen, Hermannstadt.

Boeters H. D. 1998. Mollusca: Gastropoda: Rissooidea. Süßwasserfauna von Mitteleuropa 5/1-2. Gustav Fischer, Stuttgart, Jena, Lübeck, Ulm.

BRANČSIK K. 1889. Vier neue Bythinellen aus Ungarn. Nachrbl. Dtsch. Malakozool. Ges. 20: 39-40.

FALNIOWSKI A., SZAROWSKA M., SîRBU I. 2009a. Bythinella Moquin-Tandon, 1856 (Gastropoda: Rissooidea: Bythinellidae) in Romania: species richness in a glacial refugium. J. Nat. Hist. 43: 2955-2973. doi: 10.1080/ 00222930903359636

FALNIOWSKI A., SZAROWSKA M., SîRBU I. 2009b. Bythinella Moquin-Tandon, 1856 (Gastropoda: Rissooidea: Bythinellidae) in Romania: its morphology with description of four new species. Folia Malacol. 17: 33-48. doi: 10.2478/ v10125-009-0003-2

GEORGIEV D. 2009. Bythinella gloeeri $n$. sp. a new species from a cave in Bulgaria (Gastropoda: Risooidea: Hydrobiidae). Acta Zool. Bulg. 61: 223-227.

GEORGIEV D., STOYCHEVA S. 2011. A new spring-snail species (Mollusca: Gastropoda: Risooidea) from Stara Planina Mountain, Bulgaria. Buletin Shkenkor, Series Shkencat Natyrore 61: 97-100.

GLÖER P. 2002. Die Süßwassergastropoden Nord- und Mitteleuropas. Die Tierwelt Deutschlands, 73. ConchBooks, Hackenheim.

GLÖER P., GEORGIEV D. 2009. New Risooidea from Bulgaria (Gastropoda: Rissooidea). Mollusca 27: 123-136.

GlÖER P., GEORGIEV D. 2011. Bulgaria, a hot spot of biodiversity (Gastropoda: Rissooidea)? J. Conchol. 40: 489-504.
WALKER who checked the English manuscript. The English translation was verified by SYLWIA UFNALSKA. In addition, I thank two anonymous reviewers for their helpful comments, which improved this paper.

GLÖER P., SîRBU I. 2006. Freshwater molluscs species, new for the Romanian fauna. Heldia 6: 207-216.

Grossu A. V. 1956. Fauna Republicii Populare Romîne. Mollusca III. Gastropoda Prosobranchia şi Opistobranchia. Academiei Republicii Populare Romine, București.

GROSSU A. V. 1986. Gastropoda Romaniae I. Prosobranchia şi Opistobranchia. Academiei Republicii Populare Romine, București.

JAECKEL S. G. A. 1962. Ergänzungen und Berichtigungen zum rezenten und quartären Vorkommen der mitteleuropäischen Mollusken. In: BROHMER P., EHRMANN P., Ulmer G. (eds). Die Tierwelt Mitteleuropas, 2, Quelle \& Meyer, Leipzig, pp. 25-294.

KIMAKOWICZ M. VON 1883. Beitrag zur Mollusken-Fauna Siebenbürgens. Verh. Mitt. Siebenbürg. Ver. Naturwiss. 23: $1-135$.

PAX F. 1938. Die Tierwelt der Quellen. 2. Das Goldloch bei Eifersdorf. Beitr. Biol. Galtzer Schneebergs 1938: 363-383.

QUEIROZ K. DE 2005. Ernst Mayr and the modern concept of species. PNAS 102: 6600-6607. doi: 10.1073/pnas. 0502030102

SINGH B. N. 2012. Concepts of species and modes of speciation. Current Sci. 103: 784-790.

Received: October 7th, 2012

Revised: February 2nd/February 12th, 2013 Accepted: February 18th, 2013 